\title{
Impact of National Social Investment Programmes on Poverty and Youth Unemployment in Plateau State, 2016-2019
}

\author{
Daskyes Y. Gulleng and Plangshak M. Suchi
}

\begin{abstract}
Poverty and unemployment are on the increase in Nigeria. In recognition of this situation, the Federal Government in 2016 introduced four key social investment programmes which include the Conditional Cash Transfer, N-Power, Government Enterprise and Empowerment Programme, and the Home-Grown School Feeding Programme to reduce the poverty level and promote inclusiveness. However, there are questions about the adequacy and transformative capacity of the programmes because they are alleged to be shrouded in controversies of politics, corruption, and defective implementation strategies. Against this backdrop, the essay examined the impact of these programmes on poverty and youth employment in Plateau State. Secondary and primary data were obtained from the State office of the social investment programme and two major markets in the Jos North and South Local Government areas respectively. Findings revealed inconsistencies in the implementation as it was characterised by fraudulent and sharp practices on the part of officers in charge of disbursement of funds; cumbersome bank process in accessing the Marketmoni component of the Government Enterprise and Empowerment Programme and non-involvement of market officials for adequate flow of information. The study recommends less cumbersome and more transparent processes to check corrupt practices and other excesses of officials.
\end{abstract}

Key words: Poverty, Unemployment, National Social Investment Programmes, Plateau State

\section{Introduction}

Poverty has emerged as one of the challenges of the 21 st century (Gweshengwe \& Hassan, 2020). About 1.3 billion people (22\%) across 107 developing countries live in poverty with children under age 18 constituting half of the poor. Out of this, about $84.3 \%$ of the poor people live in SubSaharan Africa and South Asia with the majority left behind in terms of access to basic needs such as nutrition, standard housing, and quality education (UNDP \& OPHDI, 2020). Widespread poverty in Africa can be attributed to population explosion, climate shocks, ill-health, conflict and displacement of people (Watkins \& Quattri, 2019). The World Economic Forum recently reported that Nigeria has overtaken India as the country with the highest number of extremely poor people in the world (Schwab,2019).

Regarding unemployment, the International Labour Organisation (ILO, 2019) estimated that 172 million (5.0\%) people worldwide were unemployed in 2018. However, youth unemployment was estimated at 13\% in 2017 and was expected to remain steady during 2018 . This means that nearly 67 million young people between 
Impact of National Social Investment Programmes on Poverty and Youth Unemployment in Plateau State, 2016-2019 73

the ages of 15 and 24 were actively searching for work but unable to find any (ILO, 2019). It appears that youth unemployment is tied to the failure of governments to establish coordinated policy efforts and active labour market programmes designed to ease employment opportunities. Although the global youth unemployment rate has remained relatively steady over the past decade, there have been significant regional variations in both prevalence and trends.

\section{Overview of Poverty, Unemployment, and issues of Social Exclusion in Nigeria}

In Nigeria, though there has been a steady growth in Gross Domestic Product(GDP) since the country came out of recession in 2017 , people are becoming poorer and inequality continues to increase (Federal Government of Nigeria, 2020). Besides, most of the workforce is in the informal sector where there is little income and job security. Hence, the likelihood of transiting out of poverty is low (FGN, 2020). Recent reports further indicate that $40 \%$ of Nigerians (i.e., 83 million people) live below the poverty line while another 25\% (53 million) are vulnerable (World Bank Nigeria, 2020). Inequality in income and job opportunities remains high and has undermined poverty reduction. Similarly, lack of job opportunities can be linked to widespread social and political unrest which has been exacerbated by the devastating impact of the COVID-19 pandemic. According to the World Bank (2020), the global recession occasioned by the pandemic has pushed about 2 million Nigerians into poverty.

Data on the unemployment rate in Nigeria indicates that it increased in 2018 compared to previous years. According to the National Bureau of Statistics (NBS, 2020), the national unemployment rate rose from $23 \%$ in the third quarter (Q3) of 2018 to $27 \%$ while underemployment rate increased from $20 \%$ to $28.6 \%$. A combination of unemployment and the underemployment rate in Nigeria for the reference period gives a total of $55.7 \%$. This means that $27.1 \%$ of the labour force in Nigeria or $21,764,617$ persons either did nothing or worked for less than 20 hours a week, making them unemployed (NBS, 2020). When people live in extreme poverty and/or are unemployed, they suffer dire consequences due to social exclusion. Government

\section{Response to Issues of Social Exclusion}

The 1999 Constitution of the Federal Republic of Nigeria (As Amended) provides the basis for social protection in line with the fundamental principles of inclusive growth, equality, security, and dignity of human life. More specifically, Chapter 2 (Sections $16 \& 17$ ) makes it obligatory for states to secure the maximum welfare, freedom, and happiness of every citizen based on social justice, and equality of status and opportunity (Section 16, 1b). It further mandates states to provide suitable and adequate shelter, food, a reasonable national minimum living wage, old age care and pensions, sick benefits, and welfare of the disabled. Section 17 subsection 3(a) provides that all citizens have the opportunity to secure adequate means of livelihood as well as the opportunity to secure suitable employment while Section 17 subsection3(g) makes a case for public assistance to the needy. 
However, this Chapter of the Constitution appears to have been ignored by past military administrations and successive democratically elected governments in the country. Today, poverty is a lived experience all over Nigeria. Perhaps, in recognition of the foregoing, the Federal Government introduced four key National Social Investment Programme (NSIP) in 2016. The four components of the NSIP are as follows: (a) N-Power; (b) Government Enterprise and Empowerment Programme (GEEP);(c) Conditional Cash Transfer (CCT); and Home Grown School Feeding Programme(HGSFP/SFP).

\section{The N-Power Programme}

The N-Power Programme is designed "to assist young Nigerians between the ages of 18 to 35 to acquire and develop life-long skills for becoming change-makers in their communities and players in the domestic and global markets" (FGN, 2020). It is targeted at graduates from the university, polytechnics, and colleges of education; the skilled, unskilled, and out-of-school youths. A monthly stipend of N30, 000.00 is paid to each beneficiary (FGN, 2017). The N-Power is grouped into two categories - N-Power graduate and N-Power non-graduate. The N-Power graduate also known as N-Power volunteers, is expected to provide teaching, instructional and advisory solutions in four key areas: (i)N-power Agro meant to provide advisory services to farmers across the country by assisting the Federal Ministry of Agriculture and Rural Development to disseminate knowledge in the area of extension services, (ii) N-Power Health is targeted at pregnant women and children obviously to reduce maternal and child mortality as well as other vulnerable members of society. Volunteers are to help promote preventive healthcare among these target groups in their communities; (iii) N-Power Teach deploys teachers to assist in primary schools in Nigeria. This will help to improve basic education delivery in the country; (iv) N-Tax volunteers are to work as community tax liaison officers in their states of residence with the state's tax authorities. They are to assist in creating awareness on tax compliance, answering online enquires, etc.

On the other hand, the N-Power Non-Graduate programme provides training and certifications in two key areas, namely: (i) N-Power Knowledge which provides incubation and acceleration of the technology and creative industries. It is primarily aimed at ensuring that participants get engaged in the market place in an outsourcing capacity, as freelancers and as entrepreneurs; (ii) N-Power Build engages and trains young unemployed Nigerians to build a new crop of a skilled and highly competent workforce of technicians, artisans and service professionals (Onah\&Olise, 2019).

\section{Government Enterprise and Empowerment Programme}

GEEP aims at providing access to financial services (loans) to traders, market women, women cooperatives, artisans, and Small and Medium Enterprises (SMEs) as well as enterprising youths, farmers, and agricultural workers. The ultimate aim of the programme is to achieve productive employment and decent work for all women and men, including young people and persons with disabilities, by providing loans of between N10, 000 and N100, 000 without interest and demand for collateral (FGN, 2017). Loans are distributed through three strategies namely; Market moni, Farmer moni and Trader moni. 
Impact of National Social Investment Programmes on Poverty and Youth Unemployment in Plateau State, 2016-2019 75

\section{National Home-Grown School Feeding Programme}

The objectives of the NHGSFP are to improve the enrolment of primary school children in Nigeria and reduce the current dropout rates from primary school which is estimated at 30 percent. The programme was also aimed at addressing the problem of out-of-school children and the poor nutrition and health status they face arising from poverty, which has affected their learning outcomes. It will also stimulate local agricultural production and boost the income of farmers by creating a viable and ready market through the school feeding programme. The programme also aims to create jobs along the value chain and provide a multiplier effect for economic growth and development (National Social Investment Office, 2017, p.8).

\section{The Conditional Cash Transfer Programme}

The CCT programme is aimed at direct cash transfer to five million poor people with the final aim of lifting them out of poverty. It is expected that 30 percent of the beneficiaries would be graduating from the lowest poverty quintile in the first year, 50 percent in the second year, and the remaining 20 percent in the third year (FGN, 2017, p.50). Each beneficiary receives N5, 000 per month. The support is conditioned on fulfilling some responsibilities that would enable recipients to improve their standard of living and hence the name Conditional Cash Transfer.

Although the NSIP has four components, this paper focuses on two: The N-Power and Government Enterprise and Empowerment Programme (GEEP). The paper looks at the impact of N-Power and GEEP in particular on poverty and youth employment. It provides answers to the following questions:

a. How has the implementation of N-Power and GEEP impacted poverty and youth employment in Plateau State?

b. What are the challenges facing the beneficiaries of these programmes in Plateau State?

c. How can the programmes be effectively implemented to reduce poverty and youth unemployment in Plateau State?

\section{Conceptual Review}

The concept of poverty has evolved along a historical path with lots of modifications to suit contemporary times. It is so fluid that it can only be understood according to the norms of particular communities allowing for differences in conditions between societies at a moment in time. This explains why it is difficult to have a unified definition of the concept even in contemporary times without reference to historical foundations. The most cited definition of poverty is captured by the UN (1998, p.1) which sees it as:

a denial of choices and opportunities, a violation of human dignity. It means a lack of basic capacity to participate effectively in society. It means not having enough to feed, and clothe a family, not having a school or clinic to go to, not 
having the land on which to grow one's food or a job to earn one's living, not having access to credit. It means insecurity, powerlessness, and exclusion of individuals, households and communities. It means susceptibility to violence, and it often implies living on marginal or fragile environments, without access to clean water or sanitation.

A distinction is often made between absolute and relative poverty. Absolute or subsistence poverty refers to a household's inability to command sufficient income to meet its basic needs for food, shelter, clothing, transportation, and education (Danaan, 2019). The UN (1995) refers to absolute poverty as a condition characterized by severe deprivation of basic human needs, including food, safe drinking water, sanitation facilities, health, shelter, education, and information. It depends not only on income but also on access to services. Relative poverty on the other hand is that which Sachs (2005) describes as the conditions of life in which basic needs are met but barely. It is a condition in which an individual or household's income falls short of the average income of the population in the society being considered.

Unemployment is generally regarded as a situation where people who are willing, able, and ready to work do not have job. Nwagu (2014) defines the unemployed as members of the economically active population who are without work but available for and seeking work, including people who have lost their jobs or who have voluntarily left work. This definition only takes into consideration persons who are without paid jobs to earn a decent living. The ILO (2019) conceptualized unemployment as a situation where persons of working age (usually persons aged 15 and above) who were not in employment, seek employment during a specified period and are available to take up employment if given a job opportunity but could not find employment. This paper draws heavily on this definition because it is more specific. NSIP is a mix of policies and programmes designed for individuals and households throughout the life cycle to prevent and reduce poverty and socioeconomic shocks by promoting and enhancing livelihoods and a life of dignity (The Federal Republic of Nigeria, 2016).

A search through the literature indicates that the current National Social Investment Programmes (NSIP) being implemented in Nigeria today are tied to the World Bank social protection and job creation programmes which consist of three core objectives: resilience, equity, and opportunity (World Bank,2019; Federal Government of Nigeria, 2020). Resilience usually consists of social insurance schemes for workers, which protect programme participants against loss of income due to illness, unemployment, old age, disability, or death of income earners. Equity on the other hand consists of safety nets or social assistance programmes, which are non-contributory transfers that are targeted at the poor or vulnerable members of the society. These programmes consist of targeted cash or in-kind transfers; price subsidies for food or energy; labour-intensive public works schemes; fee waivers for health care, education, utilities, or transport; and disaster relief schemes. They are designed to help poor individuals and households cushion the negative shocks and to ensure that they can meet their basic needs (World Bank, 2019). Finally, the opportunity objective consists of active labour 
Impact of National Social Investment Programmes on Poverty and Youth Unemployment in Plateau State, 2016-2019 77

market programmes that provide better income-earning opportunities by upgrading worker skills or facilitating mobility as well as labour policies and regulations that protect workers (World Bank, 2019). In summary, social protection programmes seek to provide households with the income support to fight poverty and invest in the human capital of their members.

\section{Methods}

Data for the study were collected through a combination of quantitative and qualitative methods. The quantitative method relied on secondary data obtained from the Plateau state Office of Social Investment Programme. The data was generated from a survey conducted by the Plateau State Office of SIP on the benefits of N-Power to beneficiaries and observed areas of need by the host communities where the beneficiaries were rendering services in 2017. A total of 566 beneficiaries across the 17 LGAs in the State were selected for that survey. The questions asked revolved around, the impact of the N-Power on the lives of the beneficiaries in terms of whether or not there was an improvement in their standard of living; their career was advanced, or they were gainfully employed. Other questions asked include whether or not it aided payment of their children's bills; offered them an opportunity to impart knowledge to the younger ones; and whether they can take care of their parents by participation in the programme.

The qualitative method involved a case study of beneficiaries of TraderMoni and MarketMoni(both of which are components of GEEP) attwo major markets in Jos Metropolis - the Plateau State Capital. The markets were; Potato Market situated at Building Material in Bukuru (Jos South LGA) and Tomato Market situated at FarinGada in Jos (Jos North LGA). Two (2) in-depth interviews (Key Informant Interviews (KII)) were conducted: first, with the Chairman, Plateau State Potato Traders Association, and secondly, the Secretary of the Jos Branch of Plateau State Traders and Marketers Association. Also, two focus group discussions(FGDs) comprising 8 youth participants were conducted (one per market) with members of the Potato market and that of the Tomato market. In sum, a total of 18 respondents participated in the interviews and the FGDs.

The interviews and group discussions focused on understanding the extent to which people benefited or were excluded from the GEEP. In particular, the questions first elicited information on the participants' perceptions of levels of poverty and youth unemployment in Jos Metropolis and Plateau State in general. It then centered on understanding how the GEEP was done in the selected markets starting with whether or not traders from the market benefit in the first place and from what component of the programme (TraderMoni or MarketMoni or both). Participants' experiences with the programme implementation and their satisfaction with the way the money was disbursed were also examined. Also, their opinions on alternative social policies the government could introduce to address the problem of poverty and youth unemployment were elicited. The choice of GEEP and N-Power components of the NSIP for in-depth analysis was influenced by their great potentials for reducing youth unemployment and poverty which are the primary focus of the paper. 


\section{Findings, Analysis and Discussion}

\section{Impact of N-Power on Youth Employment and Poverty Reduction}

With regards to the impact of N-Power, analysis of the survey report revealed that two (2) batches of youth between the ages of 25 and 35 benefitted from the job creation programme in the State since its commencement in 2016. The breakdown of the youth beneficiaries and funds disbursed to them per month by LGA is presented in table 1 below.

Table 1: Youth beneficiaries of N-Power per LGA and Amount Injected per Month in Plateau State

\begin{tabular}{|l|l|l|l|}
\hline $\mathbf{S} / \mathbf{N}$ & LGA & No of Youth Beneficiaries & Amount Per month \\
\hline 1 & BarkinLadi & $381(3.4 \%)$ & $\mathrm{N} 11,430,000.00$ \\
\hline & Bassa & $305(2.8 \%)$ & $\mathrm{N} 9,150,000.00$ \\
$\mathbf{3}$ & Bokkos & $572(5.2 \%)$ & $\mathrm{N} 17,160,000.00$ \\
\hline & Jos East & $335(3.0 \%)$ & $\mathrm{N} 10,050,000.00$ \\
$\mathbf{5}$ & Jos North & $2,936(26.6 \%)$ & $\mathrm{N} 88,080,000.00$ \\
7 & Jos South & $2,289(20.7 \%)$ & $\mathrm{N} 68,670,000.00$ \\
8 & Kanam & $336(3.0 \%)$ & $\mathrm{N} 10,080,000.00$ \\
9 & Kanke & $386(3.55)$ & $\mathrm{N} 11,580,000.00$ \\
10 & Langtang North & $382(3.5 \%)$ & $\mathrm{N} 9,120,00,000.00$ \\
11 & Langtang South & $304(2.8 \%)$ & $\mathrm{N} 23,220,000.00$ \\
12 & Mangu & $774(7.0 \%)$ & $\mathrm{N} 7,380,000.00$ \\
13 & Mikang & $246(2.2 \%)$ & $\mathrm{N} 12,630,000.00$ \\
14 & Pankshin & $421(3.8 \%)$ & $\mathrm{N} 14,040,000.00$ \\
15 & Quaanpan & $469(4.2 \%)$ & $\mathrm{N} 8,790,000.00$ \\
16 & Riyom & $293(2.7 \%)$ & $\mathrm{N} 9,840,000.00$ \\
17 & Shendam & $328(3.0 \%)$ & $\mathrm{N} 8,910,000.00$ \\
Total & Wase & $297(2.7 \%)$ & $331,620,000.00$ \\
\hline
\end{tabular}

Source: Office of Social Investment Programme, Plateau State, 2019

Table 1 indicates that the majority (54.3\%) of the N-Power graduates/beneficiaries were largely drawn from and/or deployed to only three LGAs namely: Jos North (26.6\%), Jos South (20.7\%), and Mangu (7.0\%). The remaining less than half (45.7\%) of the beneficiaries were spread across the 14 other LGAs of the state. The irony in this distribution is clear: the LGAs with the highest number of beneficiaries are among the few LGAs with lower rates of poverty and have access to relative income per household as well as infrastructure such as water and roads (Office of Social Investment Programme, Plateau State, 2019, p. 19). They also are among the few LGAs that ranked higher in the standardized scores of LGAs in Plateau state on infrastructure variables such as number of Global System Communication (GSM) subscribers per ' 000 populations; access road density $(\mathrm{km})$ per unit area; the number of commercial banks per ' 000 populations; water consumption/day per ' 000 populations; and electricity consumption/unit area (Office of Social Investment Programme, Plateau State, 2019, p. 19) 
Impact of National Social Investment Programmes on Poverty and Youth Unemployment in Plateau State, 2016-2019 79

In addition, the report indicates that over 800 candidates were trained in different skills under the N-Power non-graduate component. Some of the beneficiaries were on nine months attachment with reputable firms/organizations and they were to continue to receive their monthly stipends while on attachment because the engagement is a continuous process (Office of Social Investment Programme, Plateau State, 2019). Finally, the report also highlighted the result of a survey carried out by the Plateau State Office of Social Investment Programme in 2017 on benefits of the NPower programme as well as observed areas of need by the host communities where the beneficiaries are rendering services. The findings are summarized and presented in figures 1 below:

Figure 1: Benefits of N-Power Programme to Youth Beneficiaries in Plateau State

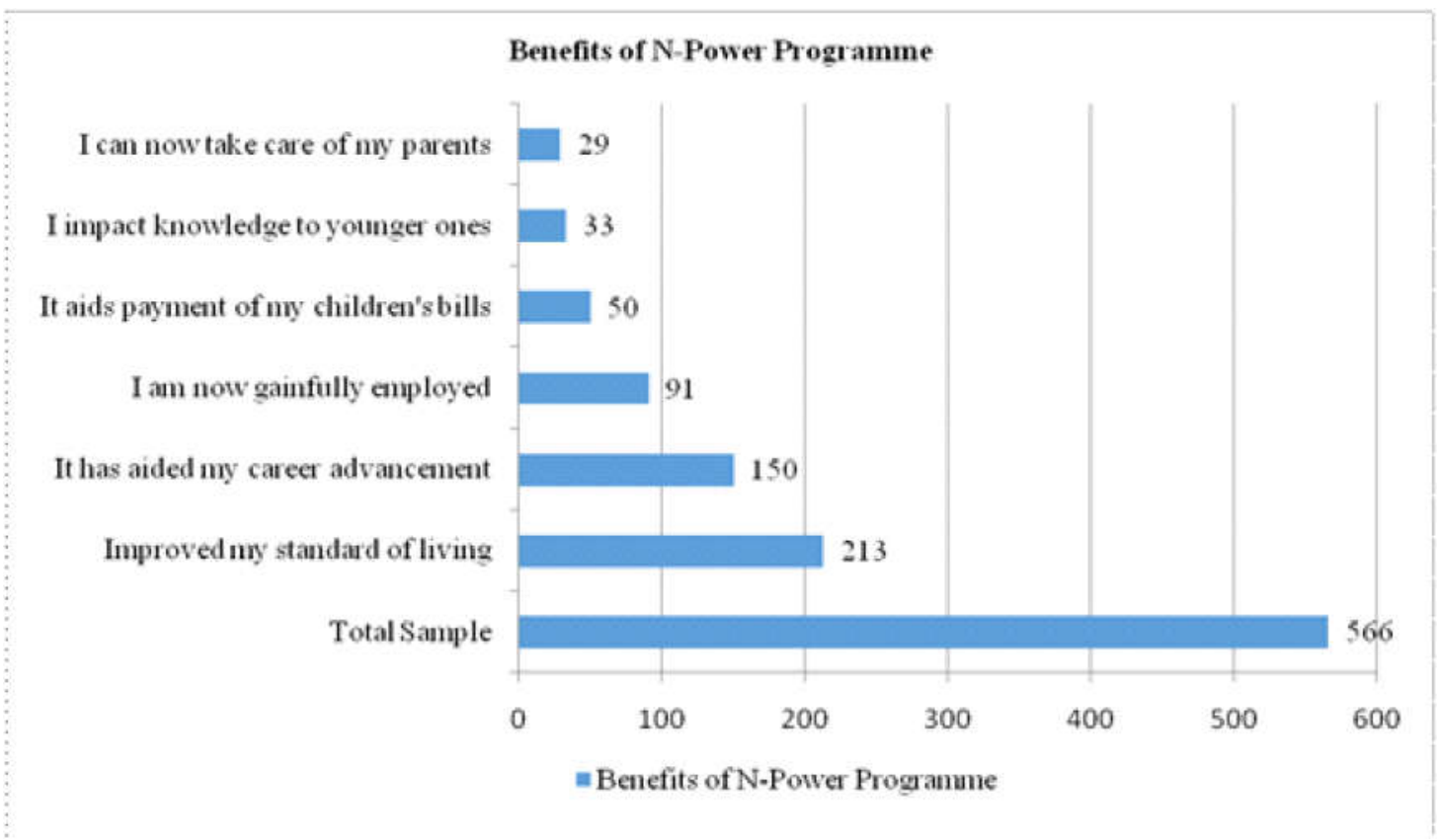

Source: Plateau State Office of Social Investment Programme, 2019

Figure1 indicates that the majority (64.1\%) of the beneficiaries of the N-Power programme in Plateau State reported that the programme either resulted in improvement in their living standard $(37.6 \%)$ or aided their career advancement $(26.5 \%)$. This signifies a positive impact on the lives of the direct beneficiaries in this regard. However, in the particular area of sustainable job creation which is the primary goal of the programme, it is instructive that only 91 out of $566(16.1 \%)$ beneficiaries indicated that the programme provided them with gainful employment. Incidentally, when beneficiaries were asked whether they observed any areas of critical need by the host community of their primary assignment, a substantial number (31\%) identified job opportunities among the critical needs of the communities. Other critical needs identified by the beneficiaries include classrooms and teaching aids, teachers, and social amenities such as pipe-borne water (Plateau State Office of Social Investment Programme, 2019, p. 13). 


\title{
Impact of GEEP on Poverty and Youth Employment in Plateau State
}

Before assessing the impact of GEEP on poverty and youth employment in Plateau State, we first gauged the perceptions of participants on the general level of poverty and youth unemployment among traders in their respective markets. As regards to poverty, the key informant at the potato market in Jos South painted the picture of a very high level of poverty among most of the traders, the majority of whom are older married women engaged in petty trading in potatoes and vegetables. Women traders were reported to be particularly hit by poverty because most of them are the backbone and breadwinners in their families. The key informant characterized the socio-economic condition of the potato market traders this way:

\begin{abstract}
My members are mainly selling potatoes and vegetables, as you just saw them outside and honestly speaking, they are suffering ranging from the farming to the sales. Before you produce and sell the potatoes, you will go through so many challenges including site selection, acquiring seeds, nursing the farm to harvest all of which are very difficult. And you can observe most of them are women and I appreciate them because they are very hardworking and they are the founding fathers of this association. Most of them have not seen the four corners of primary school, yet they are using the wisdom of King Solomon that God gave them, they are applying it and that is why some of us are here today.
\end{abstract}

The traders suffer from low patronage and a lack of capital to move their goods to cities where they can make more profits. Some days some of them make no sales at all "Some of the women cannot even afford a meal in a day", which is indicative of the level of poverty. The traders pay rent for shops but suffer from lack of basic amenities in the market such as toilets, water, and electricity. A participant describes the situation this way:

If you look at the market, there is no security, is not secured. But the LG (local government) wants money from the market, they are getting the money as soon as goods come in, they pay. We pay rent for the shops, but nothing is done, look at the landscaping, there is no toilet, there is no water, this electricity that you are seeing is the efforts of this office. And now, the government did not do anything. How do we get rich? The level of poverty will continue, but if the government would make this market a daily market- we are going to support it. Each woman that comes and gets N5 and gets back home thinks she has achieved something. If you just go along the road, buy Akamu and give your children, they will be happy with you. And some of us now, we don't want to go home on time because we have nothing to give them. You see, so I appreciate the efforts of the women, I want the government to step in.

Related to the above was the issue of youth unemployment which was also perceived to be very common in communities around the potato market in Jos South. When asked whether or not there were youths that have good skills and were willing to work but the job was not there, our key informant said:

Yes, there are. As you have seen them roaming about [the researchers could observe teeming youths exchanging drugs in form of trade and abusing the drugs within the market premises], it is a lack of job. And most of them that you see like this is not their wish, they are forced into these vices [referring to drug dealing and abuse] because there is no job opportunity.... We have youths roaming about taking dangerous drugs, which is not their wish. 
Impact of National Social Investment Programmes on Poverty and Youth Unemployment in Plateau State, 2016-2019 81

When asked whether the situation above was affecting the security of the market, the response was straight to point:

Very-very well! Daily, if I am at home, I will get a call, a shop had been broken into. Apart from the internal arrangement that the office has made towards improving security, I have four (4) security men, I pay them monthly. But that is not enough. Is not enough because, the number of youths roaming about here is more than the number of the security, and what can they do? Lack of adequate security is a major constraint to this market (Interview with Chairman, PSPTA Building Material Market, $6^{\text {th }}$ March 2020).

Similarly, focus group participants at the Tomato Market, FarinGada in Jos North shared their perceptions of the general level of poverty, youth unemployment, and insecurity in the area. With regards to poverty and youth unemployment, participants were unanimous in indicating that there was some level of poverty among their members but maintained that unemployment was a matter of choice. This was because they believed that the market accommodates diverse kinds of people and "anybody that comes to the market and exercises some patience for a little - even if it entails engaging in laborers' work will eat food"'(Organizing Secretary, PSTMA, Jos North Branch, Tomato Market, Farin Gada, $6^{\text {th }}$ March 2019). He further said,

Here in our market, if you will come and be content with little, then by the grace of God you will not lack what to satisfy your basic needs because we believe that "Biyan Bukata Sai Allah" (Hausa for "Only God can supply all our needs"). But just little enough to sustain oneself we believe will not be difficult here. Because in this life, today you have, tomorrow you don't. So, to be honest we believe that our area (Farin Gada Market) is a little bit different relative to the city centre when it comes to unemployment.

The above view received support from other participants who unanimously agreed that the problem was not youth unemployment or even laziness per se but a general tendency among children and youth to pursue what participants described as 'quick money'. They attributed what is largely perceived as unemployment in the area to impatience on the path of most youth to learn particular trades which their parents might have enrolled them in and instead, will prefer to engage in thefts around the marketplace.

However, the position of the Plateau State office of the Social Investment Programme is different. It stated that GEEP is making an impact on poverty in the State:

Over five hundred groups with more than 6000 members have benefitted from Plateau State. Some beneficiaries have already repaid back their loans. Those who have an interest in the intervention have been forwarding their applications to the Focal Person or through online registration under the website www.boi.ng/marketreg. [There are] over 8,000 beneficiaries of the MarketMoni and TraderMoni. Service is still being rendered to small-scale entrepreneurs (Office of Social Investment Programme, Plateau State, 2019 p. 21). 


\section{Impact of MarketMoni on Poverty and Youth Unemployment}

In assessing the impact of MarketMoni on poverty, respondent's perception on whether or not the programme resulted in significant improvement in the beneficiaries' business and standard of living was sought. When asked to respond to the question, from personal observation and knowledge of the condition of the few members that benefitted from the market money in 2017, the Chairman of the Potato Traders Association answered in the affirmative. In his words:

\footnotetext{
Yes, there is a significant improvement in the beneficiaries' business and living standards. Most of them have come back to appreciate the government through this office. I have seen changes in their lives; I have seen improvements in their businesses. It is a welcome idea and I appreciate it too. It is something that has taken them to the next step and is very encouraging.
}

On the question of whether the benefit also resulted in job opportunities for some youths that were hitherto idle, this was the response: "Yes. Because I have seen some of them that benefitted brought one or two people into the market. At least if you help one person, is a step forward".

\section{Impact of TraderMoni on Poverty and Youth Unemployment}

In assessing the impact of TraderMoni, participants' opinions were sought on whether or not the programme has resulted in improvement in the economic condition particularly the poverty level of those who benefitted from the scheme. Participants' response was ambivalent: first by indicating that it has positively impacted on the lives of the beneficiaries but quickly adding that because only very few (less than 10\%) of the traders benefitted, the impact may be quite minimal (Organizing Secretary, PSTMA, Jos North, $6^{\text {th }}$ March 2020). On his part, the Auditor said that "the beneficiaries used the money for the purpose for which it was given which is to trade but we cannot tell if it led to improvement in their condition of living". Overall, the popular view among the participants was that the TraderMoni made a very minimal positive impact on the lives of the beneficiaries.

\section{Challenges of Implementation of the GEEP in Jos Metropolis}

The two components of GEEP were implemented in the two markets surveyed; MarketMoni was implemented in Potato Market while TraderMoni was implemented in Tomato Market.

\section{Challenges Associated with MarketMoni Implementation}

When asked whether there were any aspects of the process of disbursing the funds that the traders did not find satisfactory, the Chairman of the Plateau State Potato Traders Association replied in the affirmative. According to him:

The first step through which the disbursement was made in 2017 was so hectic. It was through the Sterling Bank. And if a beneficiary gets to the Bank, he or she has to bring the agent and without the agent, the money will not be paid. There was a code that will be given, we were told that ATM Card will be provided. We have not seen any of that, but the money was deducted. Members suffered, after some days, some did not even get their withdrawals. I don't know whether that money was paid back or not. I am not a banker, but there is a need to improve upon the process of disbursement of the funds (Chairman, PSPTA, Potato Market, Building Material Bukuru, $6^{\text {th }}$ Marc, 2020). 
Impact of National Social Investment Programmes on Poverty and Youth Unemployment in Plateau State, 2016-2019 83

This view was the majority opinion and resonated among participants at Tomato Market which for them was the main reason why the process of disbursing the funds was never concluded in that market and therefore none of the traders benefitted. As explained by the former secretary of the association:

\begin{abstract}
MarketMoni was introduced but not fully implemented. The forms were brought to the office and traders filled but as God will have it, the funds were never disbursed because the banking requirements for most of the traders were tedious and many of them could not complete the process and also because of a perceived lack of sincerity on the part of the implementing agencies. There was pressure to complete the process before elections but banking requirements and processes were too tedious for the traders (Former Secretary, PSTMA Jos North LGA Branch, $6^{\text {th }}$ Marc, 2020).
\end{abstract}

Thus, at Potato Market (Building Material) where the MarketMoni was fully implemented and some traders benefitted, the beneficiaries were "just satisfied but not very satisfied" with the implementation process not only because of the difficulties the traders encountered with the banking procedure but also because the amount approved per trader (N50, 000) was perceived as "inadequate to make a significant difference in their business given the prevailing cost of producing and/or marketing potato" (Chairman, PSPTA, Potato Market, Building Material Bukuru, $6^{\text {th }}$ March, 2020).

\title{
Challenges Associated with TraderMoni Implementation
}

Although MarketMoni was not fully implemented at Tomato Market interviews revealed that some of the traders and marketers at that market benefitted from the TraderMoni component of GEEP. This component involved the sharing of 'free money' $(\mathrm{N} 10,000)$ to each beneficiary. As explained in the interview, the exercise took place at the market just close to the last (2019) general elections and over 500 traders benefitted including some of the officials of the association (Former Secretary, PSTMA, Jos North, $6^{\text {th }}$ March 2020). The beneficiaries were however not limited to the Tomato Market traders alone but include various clusters within and outside Jos North LGA including Bassa LGA. Most of these beneficiaries were young traders and women.

The money was paid through the beneficiaries' bank account and for those who had no bank accounts a third party was used. However, the beneficiaries' phone numbers were used to contact the beneficiaries release the money. The procedure involved registration with the implementing agency during which the prospective beneficiary's details including phone numbers were obtained. The phone numbers were then used to reach the beneficiaries at maturity of the funds and to request them to submit or send a valid account number through which the funds were paid. Thus, unlike in the case of MarketMoni which involved the filling and submission of forms, all that was required for registration for the TraderMoni was a screenshot or facial capture of the trader, the cluster he/she belongs such as Tomato market FarinGada, his/her phone number and residential address. 
The participants observed certain irregularities in the implementation of the scheme which are well articulated by the Organizing Secretary as follows:

\begin{abstract}
... at the time of disbursement which was done here in the market, what we observed is that out of 100 percent of the people who benefitted, not up to $10 \%$ were traders from our market, the majority (more than $90 \%$ ) were drawn from other clusters... if you go round the market and ask men, women, and youth traders, you will find that out of $100 \%$ beneficiaries, only fewer than $10 \%$ of the beneficiaries were traders operating in this market.
\end{abstract}

This view was the majority position among the participants and was a constant indication of their level of dissatisfaction with the process particularly the non-involvement of the officials of the traders and marketer's associations in the implementation which, for them, explains why a majority of the beneficiaries came from other distant clusters to the detriment of traders and marketers in FarinGada where the funds were shared. According to the organizing Secretary:

\begin{abstract}
A situation in which the implementing officials bypassed the leadership of the market/ traders association in the registration and payment of the beneficiaries was not the best. We think that since the association already has a comprehensive list of all registered traders in the market, liaising with the officials would have been the most effective approach. We say this because we noticed that during the registration of beneficiaries, the government implementing agencies sometimes come to the market here to carry out the exercise, and other times they simply do it at their base. When they conducted the registration here in the market, we observed that many traders from other markets came and were registered under the Farin-Gada market.

We on our part, gladly accommodated the agents because we were told it is something good from the Federal Government but to our greatest dismay, at the end of it all, we turn out to be the least among the beneficiaries even when it will be reported that all those beneficiaries were from our market - this is the truth about our experience with the tradermoni.
\end{abstract}

The participants at the FGD further revealed that the beneficiaries suffered certain deductions from the agents which reduced the amount due by over one thousand naira (N1000). The agents did this by asking the beneficiaries to pay at least $\mathrm{N} 1000$ from their pocket before effecting the transfer of the sum of $\mathrm{N} 9,950$ to their account because $\mathrm{N} 50$ goes to the banks as a service fee. To illustrate, the Deputy Chairman indicated that he benefitted $\mathrm{N} 8000$ and when asked why the total amount was short by $\mathrm{N} 2000$, he responded as follows:

Why not, the people making the payments said they came from somewhere and that the funds for Plateau State had been exhausted and closed but they through their efforts sourced for the funds from Niger State's allocation to ensure that we are also paid and this attracted a service fee of N2000 (Deputy Chairman at Group Discussion with PSTMA, Jos North, FarinGada on $5^{\text {th }}$ March 2020).

As a result of such experiences, a participant observed that one could easily notice the fraudulent process by the federal government at the point of registration; arguing that "the names registered were different from the names that eventually benefitted" (Auditor, PSTMA Jos North Branch, $6^{\text {th }}$ March 2020). Also, in expressing his disappointment with the implementation, another participant observed that the implementing agencies did not plan properly because, for him, the person who registered the prospective beneficiaries only captured the applicants' faces and nothing more: 
Impact of National Social Investment Programmes on Poverty and Youth Unemployment in Plateau State, 2016-2019 85

\begin{abstract}
And those captured waited for a week without any feedback from the officials. Another thing they did was while here they will capture a lot of applicants' faces and details but when they return to their base, they will change a lot of the details with different persons from other clusters particularly the phone numbers and account numbers. So, you will see a person in Hijab and everything but the name is Christian. So, when they call the phone number, you will find that it is different from the number of the person whose face appeared in the registration portal (Former Secretary, PSTMA, Jos North Branch, $6^{\text {th }}$ March 2020).
\end{abstract}

There was also the suspicion among participants that the names of those that eventually registered for the programme were used to pay different beneficiaries because it was noticed that their details were taken in a separate exercise book and it turned out that none of those traders benefitted.

\title{
Discussion
}

Findings from the study generally reveal that the NSIPs were implemented in Plateau State between 2016 and 2019 and have positively impacted the lives of the beneficiaries in terms of job creation and poverty reduction. In particular, the N-Power programme resulted in improvement in the beneficiaries' living standard and it aided their career advancement but the problem is sustainability. Similarly, the beneficiaries of MarketMoni witnessed significant improvement in their business and living standard, while TraderMoni was adjudged by the beneficiaries to have made a very minimal positive impact on their lives.

However, the beneficiaries identified certain challenges associated with the implementation of the programmes. These include the following: (i) Cumbersome bank process in accessing the MarketMoni; (ii) TraderMoni is characterised by fraudulent and sharp practices on the part of the officers in charge of disbursement; and (iii) non-involvement of the market officials who have adequate information about the traders in the market for effective and transparent coordination. Other findings of the study include lack of a marketing board and modern storage system for organized purchases of surplus products to cushion the twin effects of financial loss to the traders due to surplus of perishable products as well as making perishable products available during their off-season; and the need for public-private partnership (PPP) towards all-round year availability of perishable goods.

\section{Conclusion}

From the foregoing analysis and discussion, it is clear that although the objectives of NSIP were well-intended as they are focused on poverty reduction, employment generation, and general inclusiveness of the disadvantaged members of society, there is a gap between policy declaration and implementation. As the study has shown, there is no proper coordination of the various programmes embedded in the policy. Also, there is a lack of involvement of beneficiaries in the formulation and implementation of the programmes without which the policy only amounts to good intentions. The Plateau State example illustrates poor supervision which allowed the implementers to engage in fraudulent practices at every stage from enrollment to disbursement. If the processes in 
Plateau State are similar to other States', it would be difficult to achieve the purpose for which the programmes were introduced in the country. This is more so that Marketmoni and Tradermoni in particular were alleged to be monies distributed by the government in power for political campaigns during the 2019 elections.

\section{Recommendations}

Based on these findings, the following recommendations are offered towards better implementation of social investment programmes for effective reduction in levels of poverty and youth unemployment in Plateau State and Nigeria in general. To this end, it is advisable for responsible national authorities to:

(a) make the process of accessing the MarketMoni less cumbersome to beneficiaries by partnering with the leadership of the Traders and Marketers Association in disbursing the funds rather than relying solely on the banks with all their stringent requirements that are often too difficult for the average traders to satisfy;

(b) put adequate checks and balances in place to curb the excesses of the officials responsible for the disbursement of the funds and to prevent fraudulent and sharp practices;

(c) ensure that marketers and officials of traders' associations' have adequate information about their members and the targeted beneficiaries;

(d) ensure transparency in the co-ordination and implementation process of TraderMoni and MarketMoniScheme;

(e) provide basic infrastructure and amenities such as tarred road network, modern stores/shops with toilet facilities, water, and electricity to ease the cost of doing business in the markets especially during rainy season when most of the markets often become inaccessible to motorists thereby hindering the smooth movement of goods and services in the markets;

(f) provide storage facilities such as a cold room in the markets for the preservation of goods given that most of the commodities traded in the markets are perishable; and

(g) promote partnership between industries that process perishable goods farm products like tomatoes and potatoes to stop current wastages and loss of revenues. 
Impact of National Social Investment Programmes on Poverty and Youth Unemployment in Plateau State, 2016-2019 87

\section{References}

Adefila, J.O. \& Bulus, J.S. (2014) "Spatial Inequalities in Infrastructure Development in Plateau State, Nigeria”. American International Journal of Contemporary Research, 4(7), 89-97.

Adelaja, A., Labo, A, \& Eva, P. (2019) "Public Opinion on the Root Causes of Terrorism and Objectives of Terrorists: A Boko Haram Case Study". Perspectives on Terrorism, 12(3), 35-49.

Bradshaw, T. K. (2007)"Theories of Poverty and Anti-Poverty Programs in Community Development". Community Development, 38, 7-25.

Danaan, V.V. (2018)"Analysing Poverty in Nigeria through Theoretical Lenses". Journal of Sustainable Development; 11(1), 20-31.

Federal Government of Nigeria (2017)Economic Recovery \& Growth Plan, 2017- 2020. Abuja: Federal Ministry of Budget and National Planning.

Federal Government of Nigeria (2020)Nigeria Integration of the SDGs into National Development Planning: A Second Voluntary National Review. Abuja: The Office of the Senior Special Assistant to the President on SDGs.

Federal Republic of Nigeria (2016)Draft National Social Protection Policy. Abuja: Ministry of Budget and National Planning.

Gweshengwe, B. \& Hassan, N.H. (2020)'Defining the Characteristics of Poverty and theirImplications for Poverty Analysis", Cogent Social Sciences, 6(1),1768669, DOI: 10.1080/ 23311886.2020.1768669.

Holmes, R., Akinrimisi, B., Morgan, J. \& Buck, R. (2011)'SSocial Protection in Nigeria: An Overview of Programmes and their Effectiveness". Project Briefing, No. 59, September, 2011.

International Labour Organisation (2019) "Poor Working Conditions are main Global Employment Challenge". World Employment and Social Outlook - Trends 2019. Geneva: ILO.

Lakner, C., Mahler, D.G., Negre, M. \&Prydz, E.B. (2019)'How Much Does Reducing Inequality Matter for Global Poverty?". Policy Research Working Paper, No.8869, Washington DC: World Bank.

National Bureau of Statistic (2020)'Labor Force Statistics: Unemployment and Underemployment Report (Q2 2020)". Abridged Labour Force Survey Under Covid-19. NBS.

Nwagwu, J.E. (2014)"'Unemployment and Poverty in Nigeria: A Link to National Insecurity". Global Journal of Politics and Law Research2(1), 19-35. 
Office of Social Investment Programme (2019) Social Investment Programme Implementation in Plateau State 2016-2019. Jos: Office of the Social Investment Programme, Office of the Governor, Plateau State Nigeria.

Onah, C. \& Olise, C. N. (2019)"National Social Investment Programme (NSIP) and Sustainable Poverty Reduction in Nigeria: Challenges and Prospects". Journal of Humanities and Social Science, 24(10), 20-31.

Sachs, J.D. (2005)The End of Poverty. USA: Penguin Books.

Schwab, K. (ed.) (2019)The Global Competitiveness Report 2019. Geneva: World Economic Forum.

The World Bank Nigeria (2020)"Nigeria's Economy Faces Worst Recession in Four Decades, says New World Bank Report". Press Release, June 26, 2020.

United Nations Department of Economic and Social Affairs(2018)World Youth Report: Youth and the 2030 Agenda for Sustainable Development. New York: The United Nations.

United Nations Development Programme (1995)Human Development Report 1995. New York: Oxford University Press.

United Nations Development Programme (1998)Human Development Report 1998. New York: Oxford University Press.

United Nations Development Programme and Oxford Poverty and Human Development Initiative (2020)"Charting Pathways out of Multidimensional Poverty: Achieving the SDGs". Global Multidimensional Poverty Index 2020.UNDP \& OPHD.

Watkins, K. \& Quattri, M. (2019) "Child Poverty in Africa: An SDG Emergency in the Making”. Briefing Paper, London: Overseas Development Institute ODI.

World Bank (2019)Advancing Social Protection in a Dynamic Nigeria. Washington D.C: World Bank Group. 